UDC 339

DOI: https://doi.org/10.32782/2304-0920/1-80-8

Pidchosa Oleksandr

Buz Andrii

Taras Shevchenko National University of Kyiv

\title{
RESHORING POLICY: CURRENT STATE AND APPROACHES OF G7 MEMBER COUNTRIES
}

The G7 countries have clearly manifested tendencies in their national policy to implement reshoring in the context of the global trend towards economic disintegration. The degree and intensity of the return of production capacities to the national economies, the motives of the G7 countries for creating peculiarly favourable business conditions in the home country, the common and distinctive features in promoting reshoring for businesses are revealed. Specific cases of large companies (in particular MNCs) which are planning or already re-arranging their production facilities in the near future and, accordingly, are realigning global value chains are discussed. The current implications and future prospects for the G7 countries in their pursuit of reshoring policies are identified. A working hypothesis of reindustrialization is proposed as an explanation of the reshoring trend and the weakening propensity to offshoring.

Keywords: reshoring, competitiveness, strategy, reindustrialization, economic disintegration.

Introduction and problem statement. The current stage of development of the world economy is characterized by significant structural changes caused by the altering geopolitical status quo and the emergence of a new stage of technical and economic development based on a new resource in a form of high technology providing higher added value. Given the fact that each industrial revolution has led to mass replacement of one set of technologies by another by direct replacement or by modernizing the existing technologies and processes; each economy has a different potential for quick replacement of obsolete technologies with the new ones forming a large added value. That is, the potential for mastering the technologies of the new industrial revolution is one of the main factors in the formation of such an economic structure that remains competitive in the world market for a long period of time.

If institutional regulation is successful during formation of a new stage of technical and economic development, then a period of economic prosperity based on new technologies and innovations is possible in the future. This period can be a period of full employment and ubiquitous profitable investments, a time when production is at its peak ensuring progress and socio-economic stability. The desire of each state to secure leadership at a new stage of technical and economic development leads to the fact that the potential for economic development based on new technologies is provided not only through economic, but also political mechanisms of the industrial development. Reshoring, which has manifested itself as a trend in the past few years, is one of these methods of increasing the country's own industrial capital and restraining the growth of other countries.

In recent years, a policy of so-called reshoring has been emerging in industrialized countries. It consists of repatriation of production, that is, the return of industrial enterprises to their country of origin. Such enterprises include not only industrial giants, but also many medium and small enterprises. Production repatriation cases are increasingly becoming popular in economic sources, but UNCTAD reports indicate that the geography of production movement among countries is very heterogeneous in the number of moving organizations and the number of newly created jobs, which, however, does not reduce the relevance of the resolution strategy in international trade politics [29].

Analysts in the world economy note that the return of industrial enterprises back to the United
States from developing countries accelerates the process of creating new jobs. With the return of industrial enterprises to the United States, it is planned to create about 5 million jobs, which will reduce unemployment by 2-3\%. Thus, developed countries see reshoring as a means to solve the problems associated with a shortage of jobs in the context of a surplus of labour. Despite the fact that the main declared goal of resolving industrial production is to create new jobs in conditions of high unemployment, an important factor in implementation of this type of policy is to restrain economic growth in rapidly developing countries.

It is expected that the return of production capacities will restore the competitiveness of industry in countries with high wages after reindustrialization of the economy in Europe and the United States. Thus, reshoring strategy is one of the promising areas of application of methods of territorialsectoral planning focused on building the capacity of industrial production within the country by returning production capacities from developing countries.

Analysis of recent research and publications. Various aspects of the phenomenon per se and the process of implementation of reshoring have been reflected in the works of many domestic and foreign scientists. A significant contribution to the research of this problem has been made by H. Kazuyoshi, S. Wilkinson, M. Gregory, P. Arnold, D. Bailey, L. De Propris, D. McCann, G. Talamo, M. Sabatino, S. Kinkel, J. Gott, P. Bossche, B. Levering, Y. Castaco, V. Namoniuk, O. Rogach, O. Shnyrkov, R. Zablotska and others.

Highlighting previously unresolved parts of the common problem. Reshoring, as well as offshoring, is not a universal solution to all economic problems, but rather a response of mainly developed countries that have begun to lose competitive advantage to modifying economic conjuncture and is a result of their awareness of the necessity to maintain leadership in the long run. Moreover, the G7 countries' reshoring initiatives are not coincidental; their totality forms a coherent pattern. They are trying to curb the economic growth of developing countries and, in the meantime, to reindustrialize in order to implement a new wave of trade expansion in the future.

Purpose of the article. The article aims to reflect the G7 countries' concepts of reshoring, to keep track of related global regularities, to distinguish the current implications and perspectives in longrange outlook. 
Research results. Progressively, unstable factors of the world market and corresponding conditions of the domestic market direct firms from the developed countries to seek after reshoring strategy, gradually relinquishing offshoring. It is also noteworthy that the offshoring/reshoring parity in the USA was first-time achieved in 2014/2015 [1]. Rising labour cost, unreliable quality performance of suppliers in emerging economies and the added burden of logistics cost have contributed to this changing emphasis. Thence, analyzing the reshoring trends of the G7 countries is crucial in the context of an allencompassing and in-depth comprehension of world economic processes and the possibility of predicting further shifts.

As the first consideration, the President's Trump Administration has consistently urged American global firms to return to the United States through visible media coverage and providing respective economic stimuli. Fig. 1 graphically illustrates the dynamics of the effects of reshoring and foreign direct investment on announced jobs.

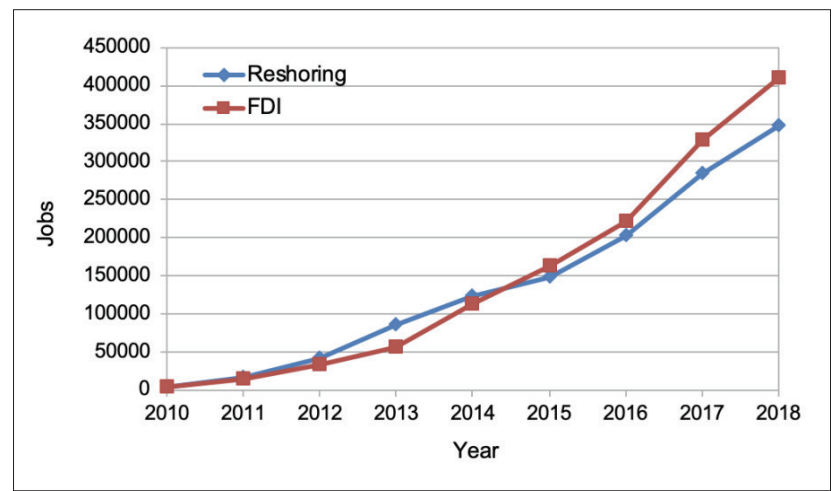

Fig. 1. Jobs Announced, Reshoring vs. FDI, Cumulative 2010-2018

Source: [2]

As for the Reshoring Initiative 2018 Data Report, the combined reshoring and related foreign direct investment (FDI) announcements remained robust, augmenting the number of jobs by more than 145,000 , with an additional 36,000 in revisions to the years 2010 through 2017. This brings the total number of announced manufacturing jobs brought to the US from offshore to over 757,000 since the employment low in manufacturing of 2010. Furthermore, the number of companies reporting new reshoring and FDI was at the most elevated level ever, up to $38 \%$ to 1389 businesses from 2017. The continued strength in occupations and the number of organizations show an unmistakable move in corporate decision making that is probably going to proliferate the pattern of reshoring and more prominent localization into the future [2].
The analysis of US reshoring cases from some countries sets a new vector for reflection. Table 1 indicates the main countries which are the objects of reshoring US enterprises. The total reshoring share is $59 \%$ from China, which is widely distributed by industry categories. FDI mainly comes from Germany (18\%) and Japan (15\%), both due to transport equipment, and more recently from China $(19 \%)$ to a wide range of industries. Most of the reshoring statements are from Asia. Western Europe used to be a major source of FDI, but now it is approximately equal from Asia, mainly due to an increment in Chinese investment.

However, noteworthy changes to US trade policy, planned for taking manufacturing back to America, are not having the expected effect. US manufactured merchandise imports from 14 largest low-costcountry (LCC) trading partners in Asia really rose by $\$ 66$ billion a year ago. That represented a $9 \%$ increase, the largest annual spike since the start of the economic recuperation 10 years prior. By comparison, US gross manufacturing output grew only $6 \%$ year over year in 2018 .

Manufacturers continue to consider LCCs as a more alluring area than the US to deliver or buy a wide assortment of merchandise, despite the trade measures exuding from Washington, D.C. First of all, the crucial financial advantages of manufacturing in LCCs have not altogether altered, and the FDI tax profits have not exceeded the essentially lower unit expenses to fabricate offshored items [3].

Undoubtedly, manufacturing in China is increasingly costly due to the tariffs, but it has already been heading in that direction as labour costs have kept on crawling upward in the course of recent years. Also, that has lately driven manufacturers to move their activities to LCCs, for example, Vietnam and India. So, instead of boosting manufacturers to reshore, the trade spat with China has just quickened this progressing shift towards those nations.

While China has remained the biggest source of US imports, from the earliest starting point of 2018 through the first quarter of the 2019 that share has tumbled from $67 \%$ to $60 \%$, as indicated by the US International Trade Commission [20]. The volume lost by China was worth $\$ 72$ billion, precisely $50 \%$ of which was caught by Vietnam.

At the point when manufacturers do think about taking production back to North America, they fairly often pick to nearshore. The decision to nearshore to Mexico or Canada is way better for the US than work remaining onward offshore like Asia. For example, exports from Mexico to the US have $40 \%$ US content while trades from China have as it were 5\% US content. Transportation facilities and apparatuses nearshore the foremost. More businesses nearshore to Mexico (90\% of nearshored jobs) than to Canada by virtue of greater cost-competitiveness.

Top 5 Countries US Reshored from, 2010-2018

Table 1

\begin{tabular}{|c|c|c|c|c|c|c|c|c|c|}
\hline \multirow{2}{*}{ № } & \multicolumn{4}{|c|}{ Reshoring } & \multirow{2}{*}{ № } & \multicolumn{4}{|c|}{ FDI } \\
\hline & Country & Jobs & Companies & $\%$ & & Country & Jobs & Companies & $\%$ \\
\hline 1 & China & 64,252 & 791 & 59 & 1 & China & 80,048 & 251 & 19 \\
\hline 2 & Mexico & 19,651 & 108 & 18 & 2 & Germany & 76,457 & 312 & 18 \\
\hline 3 & Japan & 6,615 & 35 & 6 & 3 & Japan & 64,349 & 282 & 15 \\
\hline 4 & Canada & 5,900 & 62 & 5 & 4 & Canada & 23,676 & 167 & 6 \\
\hline 5 & Singapore & 4,320 & 5 & 4 & 5 & Korea & 22,179 & 66 & 5 \\
\hline & Total & 100,738 & 1,001 & 92 & & Total & 266,709 & 1.078 & 63 \\
\hline
\end{tabular}

Source: developed by authors based on [2] 
This pattern got extensive force in the previous year, partly due to the US-China tensions, yet in addition to the progress on the United States-Mexico-Canada Agreement (USMCA).

Environmental regulation amendments, oil prices fluctuations, levied tariffs, further trade negotiations with China and possible (either favourable or disruptive) actions on USMCA are also able to make their adjustments to reshoring tendencies. An additional ambiguity is introduced by a higher level of interest rates, which, as a rule, increases the value of the US dollar, but will definitely increment the inventory carrying costs, which are expanded by offshoring.

In Canada, reshoring is less articulated - to be specific since not many Canadian organizations have exploited worldwide supply chains - though a move in manufacturing is as yet clear. The Take Back Manufacturing initiative was begun by the Society of Manufacturing Engineers (SME) in Toronto but is currently bolstered by many other management organizations, technical societies and trade associations in Ontario.

The Canadian initiative takes a more extensive point of view on reshoring than its American partners. It looks beyond the costing philosophy at government projects, instruction and preparing. It takes the view that Canada needs a fair economy with solid assets, service industries and strong manufacturing. Reshoring is especially significant in Ontario since this is the region that has endured the biggest loss of manufacturing employments.

Pursuant to the KPMG Report "Canadian Manufacturing Outlook 2014 «, just 14\% of manufacturers in Canada planned to source from China, compared to $31 \%$ a year before [21]. Canadian unit labour costs (ULC), or the average cost of labour per unit of output, rose $75 \%$ between 2000 and 2014 compared to the US, a factor which may be hindering Canadian companies from reshoring to the country [4].

According to the Financial Post, Canadian manufacturers could lose out on this drive in innovation within North American manufacturing if they do not migrate back to North America from Asia [22]. Absolutely, the Canadian government has been centered on supporting improvement of Western Canada oil and gas industries. It is contended that administration strategy and impetus which help local manufacturing, combined with education projects and apprenticeship training programmes to assist individuals with performing trades, jobs in the manufacturing segment would take the reshoring development to an unheard-of level and add to expanded thriving and higher employment levels.

The hazard, based on the vulnerability of CanadaUS trade relations, has increased with the amplified emphasis from the US government on boosting household production. The "America First" campaign highlights tax decreases for businesses and empowers the reshoring of fabrication and investments back to the US. These measures may conceivably diminish the US's dependence on Canada's imports, and displace openings for Canadian producers. To moderate the potential dangers that the Canadian industry is uncovered to, it is imperative to investigate complementary market openings and to diversify its trade portfolio [5]. In this context, reshoring is to a large degree regarded as one of the levers for solving the problem.

In case of Japan, Abe's new economic policy (i.e. Abenomics) is based upon 'three arrows' of fiscal stimulus, monetary easing and structural reforms. In response, Japanese firms overseas have considered reshoring as an attractive strategic option. The exporters confront rising labour costs crosswise over Asia, invalidating the advantages of manufacturing offshore. Simultaneously, they are finding that computerization can make domestic operations cost-competitive. Household production enables them to exhibit the "Made in Japan" label which still carries cachet.

Numerous Japanese businesses initially moved production abroad to counter a strong yen that constrained them to charge more in foreign markets, disrupting their competitiveness. Presently, the yen has returned to around 108 to the US dollar giving some relief to Japanese exporters.

Figure 2 depicts the reshoring dynamics of Japanese companies by sector of activity, providing additional evidence of an upswing in reshoring. The most recent reshoring example is Casio Computer, whose output is shared roughly equally among four plants: the Japanese site in Yamagata Prefecture, one in Thailand and two in China [6]. Casio figures that it will require under a fifth of the plant's present workforce after the investments, which, the company says, will align manufacturing costs in line with Thailand, where they are currently a fourth of those in Japan. They will likewise be lower than in China, where labour has got especially expensive by Asian standards.

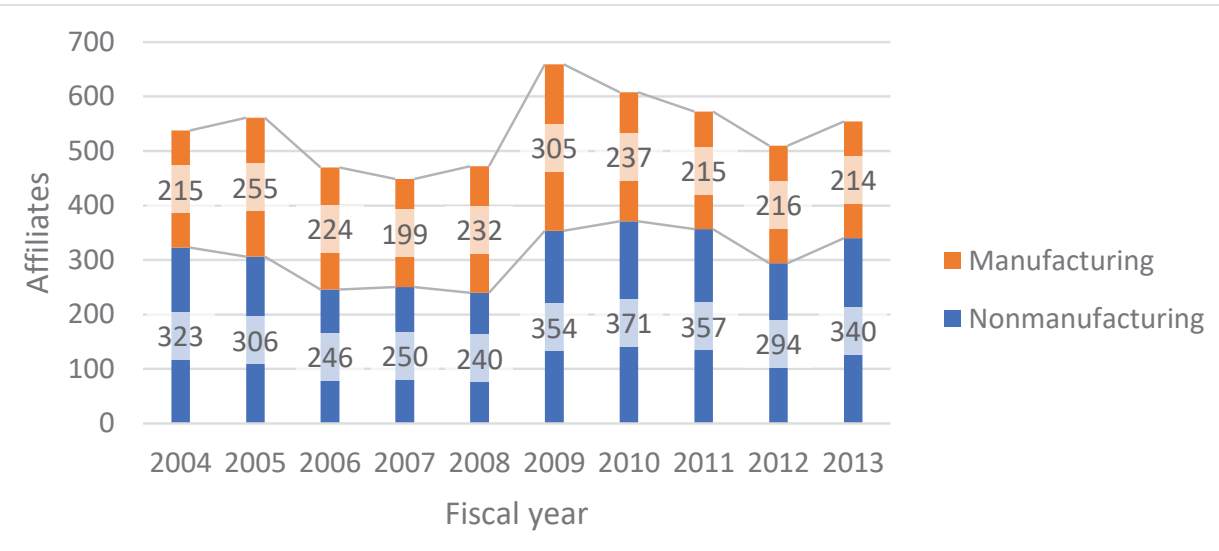

Fig. 2. Japanese Pullouts from Overseas Markets by Sector

Source: developed by authors based on [23] 
The decision is not only a proxy of rising wages in China but a necessity to create cutting-edge models corresponding to the undeniably tight eco-friendly guidelines of Asian markets. Casio's move is simply one more organization opting to put resources into Japan as opposed to overseas.

Honda's repatriation of the Super Cub comes only five years in the wake of moving production to China as an approach to cut expenses. Canon's new production line in Miyazaki is planned for using the "Made in Japan" brand by investing 23 billion yen (\$210 million) to build a facility which will be automized with artificial intelligence and robots to a great extent [7].

Although, not every industry can reshore production so effortlessly. Items where labour represents a low level of the expense are generally easy to repatriate, however, not apparel, which is workconcentrated to manufacture and quite affordable to ship. Most Japanese attire makers are moving production out of China - but to spots like Southeast Asia instead of Japan.

Reshoring can really contribute to solving the structural problems of the Japanese economy. However, as in other countries where a powerful manufacturing sector once existed, there has been a decline in recent decades, there are many unused production capacities in Japan. Companies such as Sharp and Panasonic plan to use these existing facilities when they reshore production. This will be a very good policy choice to government representatives working to stimulate economic accretion outward Tokyo [8].

In addition, Japan maintains a low unemployment rate of $2.4 \%$, albeit reshoring allows companies to engage their employees in more efficient performance work maximizing its usage. Consolidated with the predictable need to hire extra labour, as the new recruitment is gaining momentum, it can render assistance in lifting wages and ultimately putting the end to deflation.

Besides, reshoring can perchance improve government outcomes. The Abe government lately cut corporate taxes in order to make Japan an attractive spot to run business. The efforts to reshore are expected to increase revenue and taxes on the domestic activities of Japanese multinationals and provide an opportunity to magnify tax revenues.

The reshoring discussion is less prominent in Europe than in the United States. One of the underlying reasons is that European manufacturing, unlike the US, is generally less prone to offshore activities, especially in China.

In Germany, the government has developed the "Industry 4.0" Programme and offered financial incentives in order to strengthen manufacturing sectors, which indirectly facilitates reshoring. German "Industry 4.0" ensures that unit labour costs remain profitable and "Made in Germany" becomes attractive again for companies. Production in the factory is now digitally networked with technical helpers who work precisely and independently. Until recently this was expensive manual work. Even Adidas and Gigaset manufacture here again, after two decades exclusively in the Far East. Since 2008, smart phones have been produced in Germany for the first time [9].

Longitudinal information for German organizations from the German Manufacturing Survey (Erhebung 'Modernisierung der Produktion') (between 1450 and 1650 observations in the distinct studies waves between 1997 and 2012) enables us to presume that, by extrapolation, around 400 to 700 German businesses for every year have reshored their working. Cases of reshoring incorporate a German organization moving creation of intermediates by substantive suppliers in the Czech Republic back to Germany and another German organization moving fabrication once more from its Czech subsidiary.

As for the latest information from the German Manufacturing Survey of 2015, backshoring of production capacities slightly rose compared to the 2012 survey results [24; 25]. From 2013 to mid2015 , about $3 \%$ of German manufacturing companies shored parts of their foreign production capacities back to Germany (in contrast to about $2 \%$ in the previous survey).

Figure 3 outlines the distribution of German companies' reshoring decisions according to geographical principle. Less and less German companies reduce domestic production capacities in favour of foreign locations.

The foremost critical reasons for reshoring practice of German fabricating companies are the need of adaptability and delivery problems (56\%) at the offshoring area or at the end of supply chain and poor quality $(52 \%)$ of the merchandise produced. Hence, there is currently one backshoring company versus every three offshoring companies.

A share of about 3 per cent of backshoring companies is certainly not a big trend. However, it is a relevant phenomenon. When extrapolated to the entire German manufacturing sector, absolute numbers account actually for around 500 to $550 \mathrm{Ger}$ man companies performing backshoring activities per year [10]. Approximately $20 \%$ of German companies' reshoring decisions can be described as mid-term to long-term reactions to changing local environments, whereas $80 \%$ can still be designated as short- to mid-term corrections of prior location misjudgement.

Reshoring obtains increasing importance in France. France's Ministry for Industrial Renewal has developed the
Middle and Eastern EU 13 countries

- Other 
Colbert 2.0 tool, which has been available since July 2013. This tool draws its inspiration from the American Reshoring Initiative and enables companies to examine the wisdom of bringing some of their operations back to France. However, it applies a qualitative rationale, in contrast to the Reshoring Initiative's focus on cost comparisons.

Colbert 2.0 is based on an in-depth analysis of thirty recent reshoring cases conducted by the Ministry for Industrial Renewal in 2013. The cost of the reshoring operations conducted by the companies surveyed varied widely: the average reshoring cost stood at $€ 7.5 \mathrm{~m}$, but individual reshoring project costs ranged from $€ 30,000$ to $€ 40 \mathrm{~m}$. Sixty percent of these companies reported that they received central government support (business development loans, aid from local authorities, etc.) [11].

But for now, the phenomenon remains marginal. Over the period from May 2014 to September 2018, the General Directorate of Enterprises (la Direction gйnйrale des entreprises, DGE) identified only 98 reshoring cases. These would have led to creation of 2990 jobs and generated 430 million euros of investment. A brief summary is presented in Figure 4.

In detail, these relocations mainly concern metallurgy and metal product manufacturing (24\%), agro-food industries (12\%), computer, electronic and optical product manufacturing $(13 \%)$, textiles, textile clothing and footwear $(11 \%)$, and machinery and equipment manufacturing $(8 \%)$. In consonance with data from the DGE, the reshoring cases mainly concern sites relocated in Asia (52\%) and for $26.5 \%$ sites relocated in Europe, mainly from Eastern European countries. The Central region hosts the largest number of relocation cases $(13 \%)$, followed by the Hauts de France and Normandy regions, each with $10 \%$ of identified reshoring [12].

No comprehensive approach seems to be presently on the political agenda. Only sectoral interventions are envisaged, as in the case of pharmaceutical production. A Senatorial Report of September 2018 underlines that the relocation of pharmaceutical production sites, mainly concentrated in India, China and South-East Asia, threatens "the health independence" of France, and more broadly of Europe [26]. In order to promote the relocation of certain strategic productions, the Report suggests two types of measures: five-year experimentation with tax exemptions for companies planning to set up production sites in France, as well as payment of subsidies.

The reshoring phenomenon is likewise important to the manufacturing framework in Italy, described more as a rule by noteworthy reexaminations of the production models and internationalisation methodologies additionally as a response to the recent crisis. Recent studies on reshoring have focused on companies operating in Textile, Clothing, Leather and Footwear Industry (TCLF), whose items are often delicate to the "Made In" effect, demonstrate a common incentive which pushes companies working in these areas to return.

Figure 5 delineates that in connection to repatriation in Italy, the logistic expenses and production costs appear to be minor $(13 \%)$, in contrast to what occurs at worldwide level, and specifically in the USA. This can clarify the raised gap in terms of labour costs of Italia in comparison to those of customary outsourcing. Given the geographical location, reshoring strategy in Italy mainly occurs in the northern regions (97 decisions on 123), first of all, Veneto (36), Emilia-Romagna (22) and Lombardy (18) [14].

Taking into consideration these recent data and some new projects, we can presume that little has been done in Italy to encourage reshoring. Nonetheless, it is intriguing to examine the "Project re-shoring" occurring from coordinated efforts between "Sistema Moda Italia" (SMI) and PwC Advisory arranged to provide vital conditions to backshore the production and to increase the profitability in two pilot areas, Veneto and Apulia. The programme plans to elevate help to organization, requalification and instruction through an Academy yet, in addition, to gather acknowledgements by those businesses, and fundamentally by PMI, that means to conduct back-shoring. SMI has made new contacts with the production firms and it controls the condition of the initiative so as to extend it to different Italian regions [15].

Therefore, considering reshoring by the way of a further appearance to companion with the explicit national course with regards to a progressively allaround recovery of the nation's competitiveness is surely an unprecedented test both in hypothetical and more realistic parlance and in regional and territorial improvement approaches. Concentrating on Italy, it becomes clear that higher coordination between the national government and regional

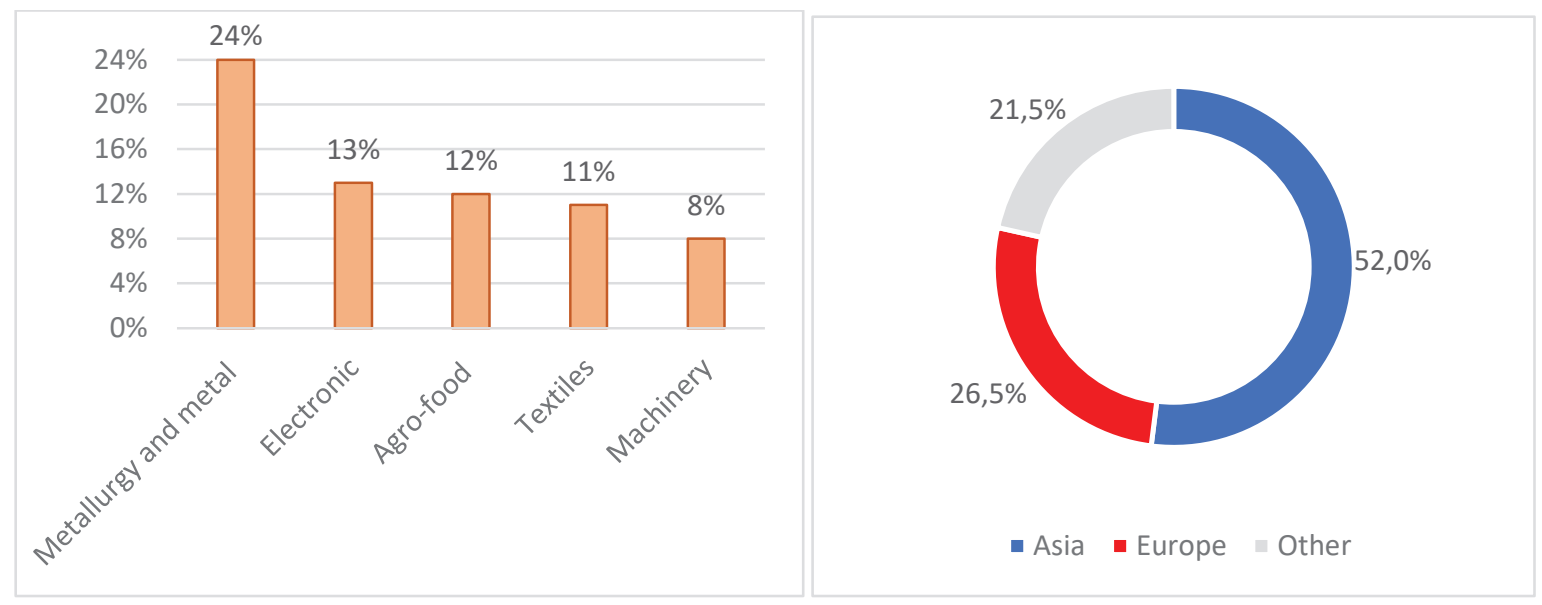

Fig. 4. France's Reshoring Cases (by industry and geographical direction)

Source: designed by authors from [13] 


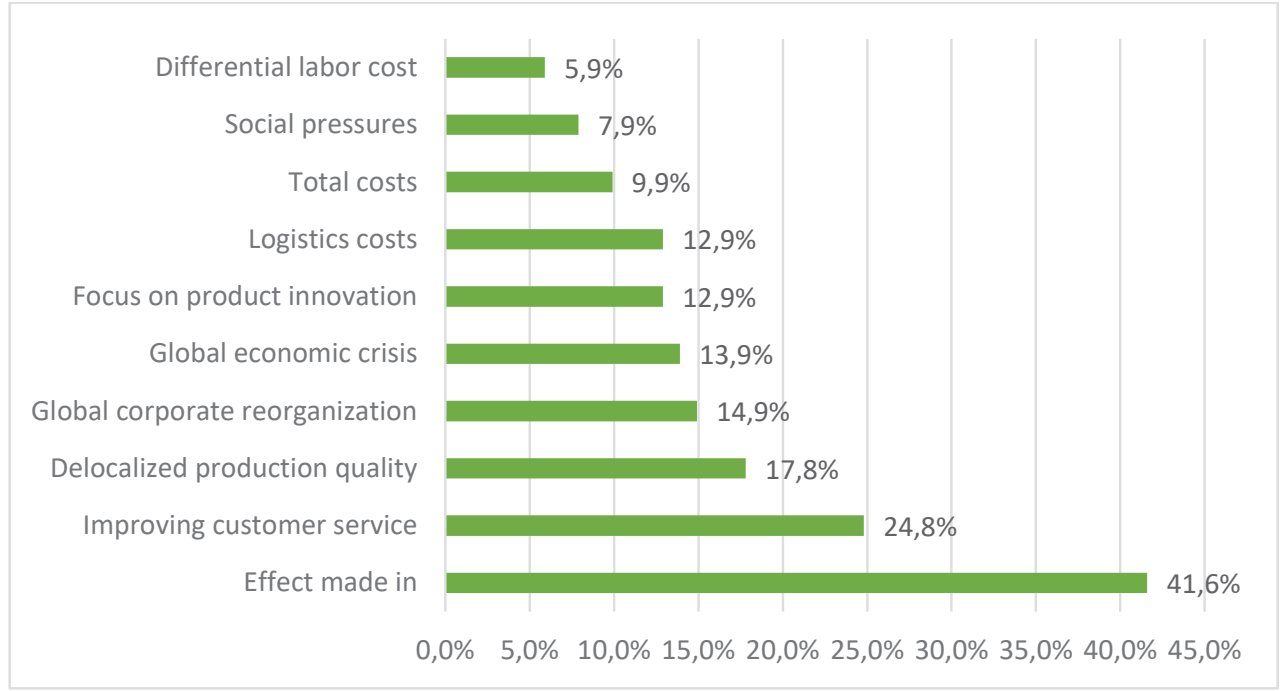

Fig. 5. Italian reshoring motivations (2016)

Source: [12]

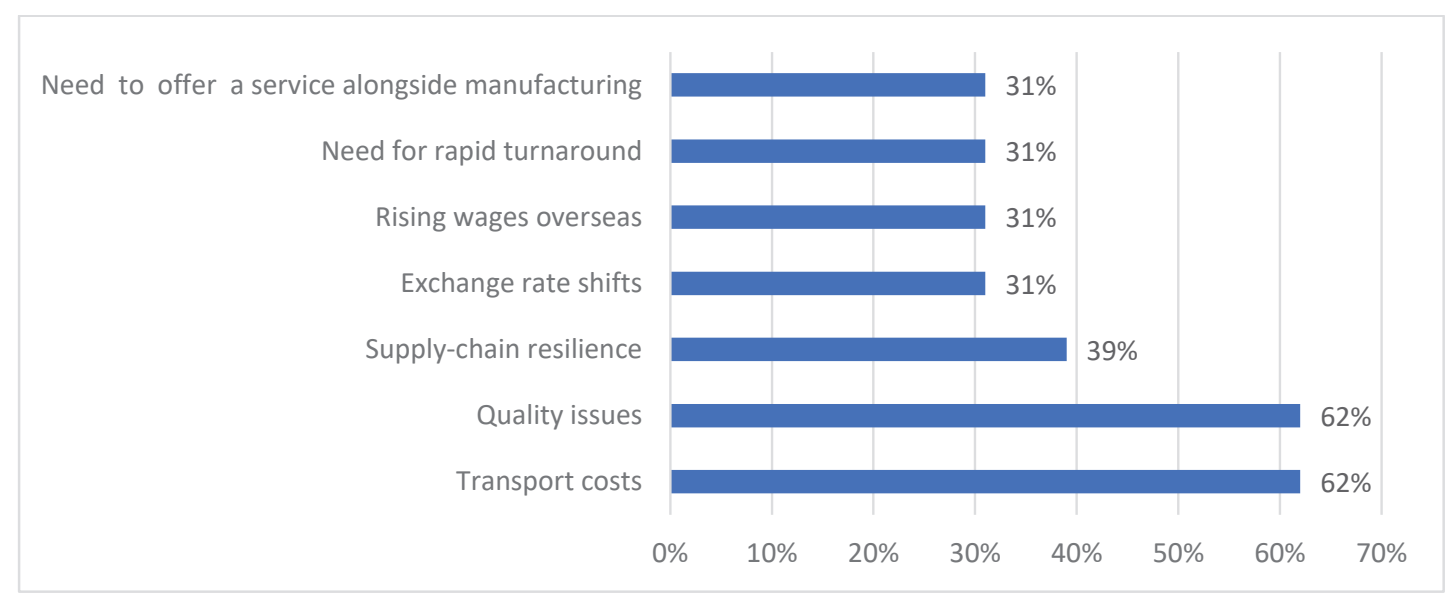

Source: [27]

Fig. 6. The most significant drivers for UK reshoring (2013)

authorities and the private sector to advance 'Made in Italy' is essential, offering proficient frameworks, area openings, workers and skills, appropriations in aid and tax alleviation.

When considering the United Kingdom, as stated in 2013 Bailey and De Propris/SGH Martineau's Manufacturing Firms' Survey in the Midlands of the UK, it was shown that around $16 \%$ of the 80 answering organizations were really embracing reshoring and 5\% actively thinking about it [27]. Figure 6 represents the main reshoring stimulation incentives for British entrepreneurs in 2013. By the same token, half of the organizations have brought back tasks from BRICS nations, 33\% from Asia, and more than one fifth from Europe. Nonetheless, it likewise distinguished the key boundaries for further reshoring to the UK like energy costs, regulation guidelines, access to funding, abilities gaps, and so on. Thus, we can assume that the vision of these problems (e.g., excessive regulation) may have become one with the harbinger of rationalizing the position about Brexit as a way to bridge the weaknesses of the UK economy.

Mentioning technical skills and gaps in abilities, it is also worth noting that Britain aims to survive Brexit by becoming global 3D printing leader. For example, the leading trade association for flexographic industry, the European Flexographic Industry Association (EFIA), expressed that vulnerability over Brexit dealings is seeing an ascent in reshoring - the way toward reintroducing household manufacturing to the UK. The EFIA states that this offers considerable chances to the print and packaging industry. However, just if companies are set up to put resources in employee training to counter the across-the-board aptitudes deficiency collided by British manufacturers [16].

In the UK, the government agency UK Trade \& Investment and the Manufacturing Advisory Service (MAS) have propelled a project called "Reshore UK" which plans to help companies to bring production back home and distinguishes reshoring as a phenomenon that may be useful to rebalance the UK economy.

Besides, the Brexit vote has fuelled the reshoring tendency, with a slump in the pound since then making imported merchandise, ingredients and parts cost much more. The outcome is that the UK manufacturers are having their busiest spell for 29 years, with exports booming and UK workers more competitive. As indicated by the report by Ernst and Young in 2015, bringing manufacturing back to the UK was a "once in a generation" opportunity that 
G7 Members' Reshoring Trends

Table 2

\begin{tabular}{|c|c|c|}
\hline $\begin{array}{c}\text { G7 } \\
\text { Member }\end{array}$ & Case & Specification \\
\hline \multirow{7}{*}{ US } & Apple & $\begin{array}{l}\text { Has reshored } 22,200 \text { jobs (Texas is benefiting) and plans to spend more than } \$ 30 \text { billion in capital } \\
\text { expenditures in the United States within the next five years. }\end{array}$ \\
\hline & $\begin{array}{l}\text { General } \\
\text { Motors }\end{array}$ & $\begin{array}{l}\text { Has brought back nearly } 13,000 \text { jobs to the states (Michigan, New York, Tennessee, Texas) and is } \\
\text { expanding several of its factories in a move that would create up to } 7,000 \text { new jobs (globally, has } \\
\text { around } 180,000 \text { workers many of whom work and reside in the US). }\end{array}$ \\
\hline & Boeing & $\begin{array}{l}\text { Has reshored some } 7,725 \text { jobs to Missouri, Montana, South Carolina as a part of the company's } \\
\text { Reshoring Initiative. }\end{array}$ \\
\hline & Ford & $\begin{array}{l}\text { Has reshored about } 4,200 \text { jobs back to the United States and is investing } \$ 700 \text { million to create } \\
\text { around } 700 \text { new jobs in a facility expansion project. }\end{array}$ \\
\hline & Intel & $\begin{array}{l}\text { Has brought back } 4,000 \text { jobs and announced plans to open the facility with a total investment } \\
\text { of } \$ 7 \text { billion and the direct hiring of } 3,000 \text { high-tech, high-wage workers (will indirectly lead to } \\
\text { creation of roughly } 10,000 \text { jobs throughout Arizona). }\end{array}$ \\
\hline & $\begin{array}{c}\text { Dow } \\
\text { Chemical }\end{array}$ & $\begin{array}{l}\text { Has reshored } 2,900 \text { jobs and plans to invest } \$ 6 \text { billion in its manufacturing plants in Texas and } \\
\text { Louisiana in an effort to capitalize on lower domestic natural gas prices. }\end{array}$ \\
\hline & $\begin{array}{l}\text { General } \\
\text { Electric }\end{array}$ & $\begin{array}{l}\text { Has reshored 2,656 jobs and is shifting its production of bottom-mounted refrigerators and front- } \\
\text { load washing machines from China and Mexico to the US due to lower transportation costs, a more } \\
\text { qualified workforce, and significant tax incentives by national and local governments. }\end{array}$ \\
\hline Canada & $\begin{array}{l}\text { Korhani } \\
\text { Home }\end{array}$ & $\begin{array}{l}\text { makes products with on-trend designs and colours with a short lead time, now manufacturing } 40 \% \\
\text { of products in Canada. }\end{array}$ \\
\hline \multirow{11}{*}{ Japan } & Canon & $\begin{array}{l}\text { aims to boost domestic production from } 40 \% \text { to } 60 \% \text { of total output by value; } \\
\text { will open new digital camera plant in Miyazaki Prefecture in } 2019 \text {, its first in nine years. }\end{array}$ \\
\hline & Pioneer & moved car navigation production to Aomori Prefecture from Thailand. \\
\hline & Honda Motor & moved production to mainstay Super Cub to Kumamoto Prefecture from China. \\
\hline & Shiseido & building a cosmetics factory in Tochigi Prefecture, the first domestic plant in 36 years. \\
\hline & Panasonic & $\begin{array}{l}\text { performs a gradual shift in production of home appliances for the Japanese market (about } \\
40 \text { products, including air conditioners, washers, and microwave ovens). }\end{array}$ \\
\hline & Sharp & $\begin{array}{l}\text { launched trial production of home air purifiers, refrigerators, etc. in December } 2014 \text { in preparation } \\
\text { for partial production shift from China to Yao Factory in Osaka Prefecture. }\end{array}$ \\
\hline & $\begin{array}{l}\text { Daikin } \\
\text { Industries }\end{array}$ & shifting production of some home air conditioners from China to Shiga Plant in Shiga Prefecture. \\
\hline & TDK & $\begin{array}{l}\text { plans incremental reshoring of about } 30 \% \text { of Chinese affiliate's production of electronic components } \\
\text { for smartphones and automobiles using idle company facilities in Akita and Yamanashi Prefectures. }\end{array}$ \\
\hline & Honda & $\begin{array}{l}\text { shifted production of some mini-bikes for the Japanese market from Vietnam to Otsu Factory in } \\
\text { Kumamoto Prefecture. }\end{array}$ \\
\hline & Nissan & hopes to boost the share of export vehicles produced in Japan in response to weak yen. \\
\hline & $\begin{array}{l}\text { Casio } \\
\text { Computer }\end{array}$ & $\begin{array}{l}\text { automating operations at a factory in Yamagata Prefecture, with plans to more than double its } \\
\text { capacity from the current } 100,000 \text { units a month; } \\
\text { within the next three years, will transfer certain production lines to Yamagata from elsewhere in Asia }\end{array}$ \\
\hline \multirow{3}{*}{ Germany } & $\begin{array}{l}\text { Deutsche } \\
\text { Bank }\end{array}$ & $\begin{array}{l}\text { Has reshored some of its financial service activities from the United Kingdom in } 2018 \text { (the main } \\
\text { motivation is Brexit since the booking of trades might not be allowed outside of the European Union). }\end{array}$ \\
\hline & Siemens & $\begin{array}{l}\text { Has moved in } 2017 \text { from its factory in Brande, Denmark, to a factory in Cuxhaven, Germany } \\
\text { (Danish knowledge and experience about wind turbines was not enough to saturate the fast-growing } \\
\text { industry) and returned } 1,000 \text { jobs. }\end{array}$ \\
\hline & Adidas & $\begin{array}{l}\text { Has produced its pilot batch of shoes using robots in } 2016 \text { (because Nike recently decided to } \\
\text { produce shoes through a robotised system) after two decades exclusively in the Far East and took } \\
\text { back } 160 \text { jobs. }\end{array}$ \\
\hline \multirow{2}{*}{ France } & Arkopharma & $\begin{array}{l}\text { decided in } 2017 \text { to close its manufacturing pharmaceutical sites in Italy and Ireland and centralize } \\
\text { the production activities in Carros (France) and returned } 160 \text { jobs. }\end{array}$ \\
\hline & Famoco & $\begin{array}{l}\text { reshoring in the sector of computer, electronic and optical products from China in } 2018 \text { (experienced } \\
\text { criticalities in managing the relationship with Chinese contractors). }\end{array}$ \\
\hline \multirow{3}{*}{ Italy } & Steelco Spa & $\begin{array}{l}\text { reshored in the sector of electrical equipment from Germany and Austria in } 2018 \text { and hiring } 60 \\
\text { people. }\end{array}$ \\
\hline & Bomboogie & $\begin{array}{l}\text { decided in } 2015 \text { to make two kinds of products (T-shirts and pants) under the brand of Bomboogie } \\
\text { in Italy as it is no longer suitable to produce them in Bangladesh and China. }\end{array}$ \\
\hline & Natuzzi & aims to backshore $50 \%$ of production currently in China and Romania. \\
\hline \multirow{7}{*}{ UK } & McLaren & $\begin{array}{l}\text { opening a J50m hi-tech factory in Sheffield - the supercar company's second plant in the UK - and } \\
\text { creating } 200 \text { jobs (at the moment, its carbon chassis parts are made in Austria). }\end{array}$ \\
\hline & Cadbury & $\begin{array}{l}\text { bringing back production of Dairy Milk bars to the UK after making some in Poland plans to invest } \\
\text { J75million into the plant; } \\
\text { will also move the production of Cadbury Dairy Milk Oreo and Cadbury Dairy Milk Tiffin from } \\
\text { Germany to Bournville. }\end{array}$ \\
\hline & Boohoo & manufactures more than half its clothes in Britain. \\
\hline & ASOS & expects to double its UK production. \\
\hline & $\mathrm{EE}$ & $\begin{array}{l}\text { all customer calls are now to be handled in the UK or Ireland (created 1,000 new jobs at its sites } \\
\text { in North Tyneside, Darlington, Plymouth and Merthyr Tydfil). }\end{array}$ \\
\hline & Vodafone & $\begin{array}{l}\text { announced plans to bring } 2,100 \text { customer service jobs back from South Africa, India and Egypt } \\
\text { (in response to complaints on unsatisfactory service) to Midlands, Scotland and Wales. }\end{array}$ \\
\hline & $\begin{array}{l}\text { Northern } \\
\text { Flags }\end{array}$ & $\begin{array}{l}\text { re-established its printing and finishing arm here after eight years when the work was outsourced } \\
\text { to Poland and Thailand. }\end{array}$ \\
\hline
\end{tabular}


could give a J15billion lift to the economy and make 315,000 jobs [28].

For instance, conforming to the Automotive Council, $44 \%$ of all parts used in autos produced in the UK are presently from British suppliers; that is up from $41 \%$ in 2016 . UK textile firms can react quickly to items demonstrating an unexpected hit, with shops restocked in days, instead of having to wait weeks for orders to land from Asia. According to the recent industry report estimation, more than 10,000 jobs could be created in Britain's textile trade throughout the following three years.

Following quite a while of decay, the segment is developing again, with textile manufacturing worth J9.1billion in 2017 [17]. In answer to complaints, various firms have brought call centre work back to the UK. Nevertheless, while the referendum outcome brought benefits for manufacturers, quitting the EU additionally represents a major risk to UK companies. The UK places a comparatively greater emphasis on reshoring in terms of the necessity to strengthen economic self-sufficiency outside the EU.

Representative reshoring cases by every G7 country are listed in the Table 2 .

Conclusions and proposals. All things considered, the increasing tendency of reshoring can be viewed through the prism of global disintegration economic trends. The geopolitical 'reshaping' of the world by hegemons causes transformation processes realized through disintegration of structures that were the cornerstone of the former world order. Accordingly, after the restructuring of ties that currently do not reflect existing economic realities, a decrease in disintegration forces can be expected.

In turn, at the microeconomic level, decisionmakers involved in reshoring might be guided by understanding different types of reshoring and how they relate to various drivers of these decisions.

Furthermore, both offshoring and reshoring are important location decisions of major business functions and facilities in response to changing market dynamics. Just as offshoring was never meant to be a permanent business solution, so is reshoring in the current circumstances. Reshoring makes sense due to shifts in labour cost differentials and because AI-empowered automation would offset labour cost pressure for tomorrow's manufacturing firms. However, given the enormous growth potential in emerging economies, it is reasonable that many global reindustrialized firms may soon make a legitimate business case for offshoring their vital business processes again - primarily for market proximity.

\section{References:}

1. Pidchosa, O., \& Namoniuk, V. (2018). Reshoring: Problems and Prospects. In Processes of Economic Disintegration in the Modern World Economy. Kyiv: PC "Kyiv University".

2. Reshoring Initiative (2019). Reshoring Initiative 2018 Data Report: A Record 1389 Companies Announce the return of 145,000 Jobs. Available at: http://reshorenow.org/content/pdf/Reshoring_Initiative_2018_Data_Report.pdf (accessed 19 October 2019).

3. Gott, J., van den Bossche, P., Levering, B. and Castaco, Y. (2019). US Trade Policy and Reshoring: The Real Impact of America's New Trade Policies. Atkearney.com. Available at: https://www.atkearney.com/operations-performancetransformation/us-reshoring-index (accessed 19 October 2019).

4. Peters, D. (2018). Why More Small Manufacturers are Choosing to Stay in Canada. The Globe and Mail. Available at: https://www.theglobeandmail.com/report-on-business/small-business/going-global/why-more-small-businessmanufacturers-are-staying-in-canada/article23823026/ (accessed 18 October 2019).

5. GMISummit.com. (2018). The Future of Manufacturing - Canada. Available at: https://www.gmisummit.com/wp-content/ uploads/2018/06/20190416_GMIS-Canada_v4.1.pdf (accessed 1 November 2019).

6. Ikeshita, Y. (2018). Robots Persuade Japanese Manufacturers to Bring Production Home. Nikkei Asian Review. Available at: https://asia.nikkei.com/Business/Trends/Robots-persuade-Japanese-manufacturers-to-bring-production-home (accessed 14 October 2019).

7. Kazuyoshi, H. (2016). Putting "Reshoring” into Perspective. Available at: https://www.nippon.com/en/behind/100100/ putting-reshoring-into-perspective.html?cx_recs_click=true (accessed 14 October 2019).

8. Allan, J. (2019). Japanese Companies, Reshoring Plans Take Shape. Investment in Japan. Available at: https://investmentinjapan.com/focus/japanese-companies-reshoring-plans-take-shape/ (accessed 3 November 2019).

9. Clement, S. (2019). "Reshoring“ - Wieso Arbeitsplatze nach Deutschland zurbckkommen. Erstes Deutsches Fernsehen (ARD). Available at: https://www.daserste.de/information/wirtschaft-boerse/plusminus/sendung/hr/industrie-viernull-100.html (accessed 16 October 2019).

10. Kinkel, S. (2018). Measuring Reshoring Trends in the EU and the US. Research Gate. Available at: https://www.researchgate.net/publication/324017487_Measuring_reshoring_trends_in_the_EU_and_the_US (accessed 16 October 2019).

11. Bellanger, E. (2018). Relocalisation en France: Encore un Effort!. EcoRйseau Business. Available at: https://www.ecoreseau.fr/entreprendre/enquete-entrepreneuriale/2018/12/18/relocalisation-en-france-encore-un-effort/ (accessed 16 October 2019).

12. De Backer, K. et al. (2016). Reshoring: Myth or Reality? OECD Science, Technology and Industry Policy Papers, No. 27, OECD Publishing, Paris. http://dx.doi.org/10.1787/5jm56frbm38s-en (accessed 16 October 2019).

13. Direction Gйnйrale des Entreprises (DGE). (2019). Йtudes et statistiques - Accueil. Available at: https://www.entreprises. gouv.fr/etudes-et-statistiques (accessed 6 November 2019).

14. Talamo, G. and Sabatino, M. (2018). Reshoring in Italy: A Recent Analysis. Contemporary Economics, vol. 12, no. 4 (special issue), pp. 381-398. Available at: https://ssrn.com/abstract=3377315 (accessed 3 November 2019).

15. Giuseppina, T. and Michele, S. (2019). Re-Shoring and Resilience in Italy during and after the Crisis. SCIRP. Available at: https://www.scirp.org/journal/PaperInformation.aspx?paperID=84536\& (accessed 9 November 2019).

16. Williamson, J. (2018). Brexit Reshoring Drive Reveals UK Skills Shortage. The Manufacturer. Available at: https://www.themanufacturer.com/articles/brexit-reshoring-drive-reveals-uk-skills-shortage/ (accessed 15 October 2019).

17. Hiscott, G. (2017). Britain is Back in Business as Firms Start 'Reshoring' Manufacturing to the UK. Mirror. Available at: https://www.mirror.co.uk/news/business/britain-back-business-firms-start-10738604 (accessed 15 October 2019).

18. European Reshoring Monitor. (2019). Reshoring Cases. Available at: https://reshoring.eurofound.europa.eu/reshoringcases (accessed 17 October 2019).

19. Pidchosa, O., \& Buz, A. (2019). Reshoring Policy: Approaches of G7 Member Countries. In Geo-economic Challenges for G7 Countries: Proceedings of International Scientific Conference. Kyiv, Ukraine: Institute of Economics and Forecasting of the National Academy of Sciences of Ukraine. Access mode: http://ief.org.ua/docs/scc/14.pdf (accessed 15 October 2019).

20. McCann, D. (2019). U.S. Trade Policy Fails to Reshore Production. CFO. Available at: https://www.cfo.com/globalbusiness/2019/07/u-s-trade-policy-fails-to-reshore-manufacturing/ (accessed 5 November 2019). 
21. Canadian Manufacturing Outlook 2014 (2014). Available at: https://www.manufacturingbc.org/wp-content/uploads/ Canadian-Manufacturing-Outlook-2014.pdf (accessed 5 November 2019).

22. Ovsey, D. (2013). How U.S. Reshoring will Force Canadian Manufacturers to innovate - and Change the Very Nature of the Sector. Financial Post. Available at: https://business.financialpost.com/executive/smart-shift/how-u-s-reshoring-willforce-canadian-manufacturers-to-innovate-and-change-the-very-nature-of-the-sector (accessed 11 November 2019).

23. Kazuyoshi, H. (2015). Putting "Reshoring" into Perspective. Available at: https://www.nippon.com/en/behind/100100/ putting-reshoring-into-perspective.html (accessed 19 November 2019).

24. Jдger, A. and Maloca, S. (2016). Dokumentation der Umfrage Modernisierung der Produktion 2015. Karlsruhe: Fraunhofer ISI.

25. Jдger, A. and Maloca, S. (2013). Dokumentation der Umfrage Modernisierung der Produktion 2012. Karlsruhe: Fraunhofer ISI.

26. Decool, J. (2018). Rapport d'information fait au nom de la mission d'information sur la pйnurie de mŭdicaments et de vaccins. Senat.fr. Available at: https://www.senat.fr/rap/r17-737/r17-7371.pdf (accessed 27 November 2019).

27. Bailey, D. and De Propris, L. (2015). Manufacturing Reshoring and its Limits: the UK Automotive Case. Pure.aston.ac.uk. Available at: https://pure.aston.ac.uk/ws/portalfiles/portal/17934640/Bailey_De_Propris_final_paper_for_CJRES.pdf (accessed 11 December 2019).

28. Wilkinson, S., Gregory, M. and Arnold, P. (2015). Reshoring Manufacturing - time to Seize the Opportunity. Criticaleye. com. Available at: https://www.criticaleye.com/inspiring/insights-servfile.cfm?id=4282 (accessed 20 December 2019).

29. UNCTAD (2019). World Investment Report 2019: Annex Tables. Available at: https://unctad.org/en/Pages/DIAE/ World\% 20Investment\% 20Report/Annex-Tables.aspx (accessed 29 October 2019).

30. Rogach, O. The Theory of Multinational Enterprise and Contemporary Trends in International Production / Stratehiia Rozvytku Ukrainy, № 2, 2017, pp. 14-20.

Подчеса А. В.

Буз А. А.

Киевский национальный университет имени Тараса Шевченко

\title{
ПОАИТИКА РЕШОРИНГА: ТЕКУЩЕЕ СОСТОЯНИЕ И ПОАХОАЫ СТРАН-ЧАЕНОВ G7
}

\begin{abstract}
Резюме
В статье были определены четкие проявления тенденций в национальной политике стран «Большой семерки" (G7) к поддержке внедрения решоринга в контексте мирового тренда экономической дезинтеграции. Раскрыто степень и интенсивность возвращения производственных мощностей в национальные экономики, отслежены общие и отличительные черты в продвижении моделей решоринга для предприятий в соответствующих государствах. В частности, страны G7 создают особо благоприятные условия для ведения бизнеса на своей территории. Приведены примеры, когда крупные компании (в частности, MHК), которые в ближайшем будущем планируют или уже перемещают свои производственные мощности и, соответственно, переориентируют цепи создания стоимости. Были определены текущее состояние и будущие перспективы для стран G7 от проведения политики решоринга. Рабочая гипотеза о реиндустриализации была предложена в рамках объяснения тенденции к решорингу и ослабления склонности к офшорингу.

Ключевые слова: решоринг, конкурентоспособность, стратегия, реиндустриализация, экономическая дезинтеграция.
\end{abstract}

Підчоса О. В.

Буз А. О.

Київський національний університет імені Тараса Шевченка

\section{ПОАІТИКА РЕШОРИНГУ: ПОТОЧНИЙ СТАН ТА ПІАХОАИ КРАЇН-ЧАЕНІВ G7}

Стаття присвячена дослідженню поточного стану та підходів до реалізації політики решорингу країн «Великої сімки» (G7). У роботі визначено чіткі прояви тенденцій у національній політиці країн G7 до підтримки решорингу в контексті глобального тренду до економічної дезінтеграції. Розкрито ступінь та інтенсивність повернення виробничих потужностей до національних економік, досліджено спільні та відмінні риси у просуванні моделей решорингу для підприємств країн G7. У статті наводяться результати дослідження ефектів економічної політики США, яка мали на меті створити стимули для повернення виробництв до країни, - і здійснюється їх оцінка. Також розглядаються основні засади процесу решорингу Канади. Аналізуються особливості урядової політики Японії націлені на активізацію решорингу та підвищення привабливості країни для ведення бізнесу БНП. Вивчається підхід уряду Німеччини до решорингу в рамках програми «Індустрія 4.0» і запропоновані фінансові стимули для зміцнення виробничого сектору. Розглядається політика решорингу Франції, яка на даний момент носить характер секторального втручання та стимулювання повернення окремих виробництв. Здійснюється оцінка впливу та результатів решорингу на структуру виробництва Італії, що, характеризуються змінами моделей виробництва та підходами до інтернаціоналізації. У ході дослідження робиться висновок про те, що Велика Британія приділяє відносно більшу увагу політиці решорингу порівняно з іншими європейськими країнами з огляду на об'єктивну необхідність зміцнити економічну самозабезпеченість після виходу з ЄС. У статті наведено емпіричні приклади решорингу для кожної з країн G7 та здійснено їх специфікацію. Для пояснення тенденції до решорингу та послаблення схильності до офшорингу компаній зазначених країн була запропонована робоча гіпотеза про необхідність реіндустріалізації, що була підтверджена у ході дослідження. Наведені приклади, коли великі компанії, зокрема, багатонаціональні компанії, в межах решорингу в найближчому майбутньому планують або вже переміщують свої виробничі потужності i, відповідно, переорієнтують ланцюги створення вартості.

Ключові слова: решоринг, конкурентоспроможність, стратегія, реіндустріалізація, економічна дезінтеграція. 